\section{Effect of integrated nutrient management in sunflower (Helianthus annuus L.) on alluvial soil}

\author{
Aritra Kumar Mukherjee ${ }^{1, *}$, Sudipta Tripathi ${ }^{1}$, \\ Subhadeep Mukherjee ${ }^{1}$, R. B. Mallick ${ }^{2}$ and \\ Anannya Banerjee ${ }^{3}$ \\ ${ }^{1}$ Department of Agricultural Chemistry and Soil Science, and \\ ${ }^{2}$ Department of Agronomy, Institute of Agricultural Sciences, \\ University of Calcutta, 51/2, Hazra Road, Kolkata 700 019, India \\ ${ }^{3}$ IRDM Faculty Centre, School of Agriculture and Rural Development, \\ Ramakrishna Mission Vivekananda University, Narendrapur, \\ Kolkata 700 103, India
}

Sunflower, an important oil seed crop, needs a balanced nutrition for its optimum growth and thorough maintenance of soil health. A field experiment was conducted to study the impact of integrated use of organic, inorganic and biofertilizers on soil fertility, soil organic carbon fractions, soil microbiological and biochemical parameters as well as yield of sunflower (cv. GK 2002) in alluvial soil at Agricultural Experimental Farm, University of Calcutta, Baruipur, India, during 2013-14 and 2014-15. There were ten different treatments with three replications. After analysis, the data clearly showed significant difference among treatments in sunflower yield and a prominent impact of integrated use of organic, inorganic and biofertilizers was found under the treatments. Microbial biomass carbon, basal soil respiration, activities of soil enzyme and different carbon fractions showed higher values for those treatments where only organic inputs were given. The best possible combination for higher seed yield was recorded in $T_{10} / T_{6}$ treatment (vermicompost $2.5 \mathrm{t} \mathrm{ha}^{-1}$ or FYM $\left(5 \mathrm{t} \mathrm{ha}^{-1}\right)$ with phosphate solubilizing bacteria@8 $\mathrm{kg} \mathrm{ha}^{-1}$ soil application + Azotobacter (a) $8 \mathrm{~kg} \mathrm{ha}^{-1}$ soil application $+50 \%$ recommended dose of chemical fertilizers + foliar spray ( $2 \%$ urea)). $T_{10} / T_{6}$ treatment is thus recommended for sunflower cultivation in alluvial soil considering the soil quality and seed yield of sunflower.

Keywords: Alluvial soil, carbon fractions, fluorescein diacetate hydrolysing activity, integrated nutrient management, microbial biomass, seed yield, sunflower.

EMERGING evidence indicates that management of soil fertility constraints depends on the judicious use of combined organic and inorganic resources ${ }^{1}$. Organic, inorganic or microbial fertilizer has both advantages and disadvantages for nutrients supply which affect soil health and crop quality. So, there is a need to develop an efficient nutrition management system for enhancing sustainable agricultural production and to safeguard the environment.

\footnotetext{
*For correspondence. (e-mail: joinaritra@gmail.com)
}

Soil organic matter (SOM) plays a key role in maintaining soil health. It has a strong influence on living organisms present in the soil and their beneficial functions. Management of SOM and plant nutrients is a major part of sustainable agricultural systems which can be done through judicious application of inorganic fertilizers with organic inputs such as animal manures, biological nitrogen $(\mathrm{N})$ fixation, crop residues and green manures. Soil organic matter controls soil microbial populations and their related functions in soil, such as decomposition and nutrient cycling. Application of organic manure in combination with inorganic fertilizers was found to be beneficial for health of the soil and also increased the available as well as total soil organic carbon, macro, secondary and micro nutrients status and improved soil microbial growth $^{2,3}$. Soil microbial and enzyme activity also responds well to proper crop and soil management practices such as integrated use of organic and inorganic fertilizers ${ }^{4}$. Such combinations of different organic and inorganic nutrient sources vary depending on the local land-use system and the ecological, social and economic conditions.

Sunflower is a day neutral, short duration, drought and salinity tolerant oil seed crop belonging to the family Compositae. Among the different edible oil producing crops, it is one of the most important annual crops in the world. In India, sunflower is cultivated in states like Karnataka, Andhra Pradesh, Maharashtra, Punjab, Haryana, Uttar Pradesh, Madhya Pradesh and West Bengal covering an area of $0.33 \mathrm{~m}$ ha with a production of 0.21 million tonnes and productivity of $738 \mathrm{~kg} \mathrm{ha}^{-1}$ during 2017-18 (ref. 5). In West Bengal (during 2016-17) sunflower was grown in an area of $0.01150 \mathrm{~m}$ ha with a production of 0.01509 million tonnes and a productivity of $1312 \mathrm{~kg} \mathrm{ha}^{-1}$ (ref. 6). Sunflower cultivation in West Bengal is mostly restricted in the districts of Uttar and Dakshin Dinajpur, Malda, Murshidabad, Purulia, Nadia and South 24 Parganas. Sunflower grown in February/March gives quality performance in Gangetic alluvial zone ${ }^{7}$. It is considered to be an exhaustive crop. Even though the area under sunflower crop is increasing, the productivity is not on par with the cultivable area. Among the several reasons attributable to low productivity, inadequate and imbalanced nutrition of essential nutrients is considered as a major one.

With this backdrop the proposed experiment was undertaken to evaluate the impact of conjoint application of inorganic, organic and biofertilizers on crop yield, soil carbon pools, microbial biomass and activity in sunflower production under Gangetic alluvial soil.

The two-year study was carried out at the Agricultural Experimental Farm $\left(88^{\circ} 26.164^{\prime} \mathrm{E}\right.$ and $\left.22^{\circ} 22.526^{\prime} \mathrm{N}\right)$, University of Calcutta, Baruipur, 24 Parganas (South) in the Gangetic alluvial region of West Bengal across two successive seasons of January to May 2014 and 2015, to study the effect of combined application of inorganic and 
organic fertilizer (vermicompost (VC) and farm yard manure (FYM)) with biofertilizer (including the genera $\mathrm{Azo}$ tobacter, and phosphate solubilizing bacteria) on yield and general physico-chemical, biological and biochemical properties of soil of hybrid sunflower (c.v. GK-2002).

The experiment was laid out in a randomized block design with three replications in $4 \mathrm{~m} \times 4 \mathrm{~m}$ plot size. The nutrient contents of FYM and VC are shown in Table 1. Compost was added and mixed thoroughly in soil one week before seeding. Full doses of phosphatic and potassic fertilizers were applied to the respective plots during land preparation. Nitrogen $(\mathrm{N})$ was applied in two splits, half the $\mathrm{N}$ during land preparation as basal and other half after 30 days of sowing (DAS). Nitrogen as urea, phosphate as single super phosphate and potash as muriate of potash were applied to the soil. The experiments included ten treatments as follows

Control without inputs $-\mathrm{T}_{1}$

$100 \%$ Recommended doses of chemical fertilizer (RDF) $-\mathrm{T}_{2}$

Well decomposed FYM $\left(10 \mathrm{tha}^{-1}\right)-\mathrm{T}_{3}$

FYM $\left(10 \mathrm{t} \mathrm{ha}^{-1}\right)+$ phosphate solubilizing bacteria (PSB) + Azotobacter $-\mathrm{T}_{4}$

FYM $\left(5 \mathrm{t} \mathrm{ha}^{-1}\right)+\mathrm{PSB}+$ Azotobacter $+50 \% \mathrm{RDF}-\mathrm{T}_{5}$

FYM $\left(5 \mathrm{t} \mathrm{ha}^{-1}\right)+\mathrm{PSB}+$ Azotobacter $+50 \% \quad \mathrm{RDF}+$ foliar spray (2\% urea) $-\mathrm{T}_{6}$

$\mathrm{VC}\left(5 \mathrm{tha}^{-1}\right)-\mathrm{T}_{7}$

$\mathrm{VC}\left(5 \mathrm{t} \mathrm{ha}^{-1}\right)+\mathrm{PSB}+$ Azotobacter $-\mathrm{T}_{8}$

$\mathrm{VC}\left(2.5 \mathrm{t} \mathrm{ha}^{-1}\right)+\mathrm{PSB}+$ Azotobacter $+50 \% \mathrm{RDF}-\mathrm{T}_{9}$

$\mathrm{VC} \quad\left(2.5 \mathrm{tha}^{-1}\right)+\mathrm{PSB}+$ Azotobacter $+50 \% \mathrm{RDF}+$ foliar spray $(2 \%$ Urea $)-\mathrm{T}_{10}$.

Inoculation was carried out by dipping the sunflower seeds in the cell suspension of $10^{8} \mathrm{CFU} / \mathrm{ml}$ for $15 \mathrm{~min}$. Local isolates, Azotobacter and phosphate solubilizing bacteria as well as VC used in this study were supplied by the Department of Agricultural Chemistry and Soil Science, University of Calcutta.

The field was cultivated about $20 \mathrm{~cm}$ deep. Before seeding, it was subsequently disked twice for loose and friable seed bed. Seeding was accomplished on 22 January 2014 and 16 January 2015 by putting two to three seeds at each hill maintaining a proper spacing of $60 \mathrm{~cm} \times 30 \mathrm{~cm}$. Thinning was undertaken after 15 DAS to maintain optimum plant population. Two times hand

Table 1. Physico-chemical characteristics of FYM and VC

\begin{tabular}{lcc}
\hline Parameters & FYM & VC \\
\hline Moisture per cent & 22 & 20 \\
Organic carbon (per cent dry weight basis) & 24.5 & 23.9 \\
Total nitrogen (per cent dry weight basis) & 1.09 & 1.01 \\
Available phosphorous (per cent dry weight basis) & 0.31 & 0.29 \\
Available potassium (per cent dry weight basis) & 0.86 & 0.79 \\
\hline
\end{tabular}

CURRENT SCIENCE, VOL. 117, NO. 8, 25 OCTOBER 2019 weeding for control of weeds with one hand hoeing for aeration in the soil was done during the growth period. Irrigation was given three times during the whole growing season.

Heads from net plot were cut, rubbed against ground and seeds were separated and cleaned by winnowing. Weight of sun dried seed in terms of $\mathrm{kg}$ per net plot was recorded and projected as $\mathrm{tha}^{-1}$.

Initial randomized surface $(0-20 \mathrm{~cm})$ soil samples were taken from the experimental site before seeds were sown. Another soil sampling was done during the flowering stage of the sunflower from all the 30 experimental plots. The soil samples were brought to the laboratory and air-dried for analysis of their general physico-chemical properties, while field moist soil samples were used for microbiological and biochemical analysis. Soil $\mathrm{pH}$ was measured in a $1: 2.5$ soil-water suspension using a glass electrode $^{8}$. Soil electrical conductivity (EC) was determined by measuring the electrical conductance of soil water $(1: 5)$ solution $^{8}$. Organic carbon of soil was determined by Walkley and Black method ${ }^{9}$. Total $\mathrm{N}$ of soil was determined by Macro-Kjeldahl method with the help of Kelplus automated $\mathrm{N}$-analyzer ${ }^{10}$. Available phosphorus and available potassium contents were measured by Olsen's method ${ }^{11}$ and flame photometric method using neutral normal ammonium acetate as extractant ${ }^{12}$ respectively.

The microbial biomass carbon (MBC) was determined following the chloroform fumigation extraction (CFE) method using a recovery factor $(\mathrm{Kec})$ of 0.38 according to Vance et al. ${ }^{13}$. The basal soil respiration (BSR) was measured according to the method of $\mathrm{Alef}^{14}$, with some modifications like: $20 \mathrm{~g}$ of field moist soil was taken in a $500 \mathrm{ml}$ airtight conical flask with a hanging vial containing $10 \mathrm{ml}$ of $1 \mathrm{M} \mathrm{NaOH}$ and was incubated for 10 days in the dark at $25^{\circ} \mathrm{C}$. The $\mathrm{CO}_{2}-\mathrm{C}$ evolved was determined by titration method at every 2 days interval and was calculated based on cumulative $\mathrm{CO}_{2}$ evolution over a 10-day period. The substrate (glucose)-induced respirations ${ }^{14}$. The fluorescein diacetate hydrolysing activity (FDHA) of the soils were measured based on Alef's research ${ }^{15}$.

Water soluble carbon was analysed based on the method Vance et $a .^{13}$ and the total carbohydrate carbon present in the soil was estimated by anthrone method ${ }^{16}$. Humus carbon of soil ${ }^{17}$ was also determined.

Analysis of variance (ANOVA) was carried out by randomized block design (RBD) using SPSS 11.0 statistical package. The least significant difference (LSD) test was applied to evaluate the significance of differences between individual treatments. The treatment means were compared by Duncan's multiple range tests at $P=0.05$.

The soil $\mathrm{pH}$ exhibited statistically significant difference among the treatments (Table 2). Soil pH for all the treatments showed neutral to slightly alkaline nature varying from 6.66 to 7.25 . The highest $\mathrm{pH}$ was observed in $\mathrm{T}_{9}$ treatment (7.25) in which $\mathrm{VC}, \mathrm{AZ}$ and PSB were 
Table 2. Physico-chemical properties, microbial biomass and its activities of soil under different treatments

\begin{tabular}{|c|c|c|c|c|c|c|c|c|c|c|c|}
\hline \multirow[b]{2}{*}{ Soil properties/yields } & \multicolumn{10}{|c|}{ Treatments } & \multirow[b]{2}{*}{ Initial value } \\
\hline & $\mathrm{T}_{1}$ & $\mathrm{~T}_{2}$ & $\mathrm{~T}_{3}$ & $\mathrm{~T}_{4}$ & $\mathrm{~T}_{5}$ & $\mathrm{~T}_{6}$ & $\mathrm{~T}_{7}$ & $\mathrm{~T}_{8}$ & $\mathrm{~T}_{9}$ & $\mathrm{~T}_{10}$ & \\
\hline $\mathrm{pH}(1: 2.5)$ & $7.02^{\mathrm{b}, *}$ & $6.96^{\mathrm{c}}$ & $6.77^{\mathrm{f}}$ & $6.82^{\mathrm{e}}$ & $6.88^{\mathrm{d}}$ & $6.76^{\mathrm{f}}$ & $6.97^{\mathrm{c}}$ & $6.66^{\mathrm{g}}$ & $7.25^{\mathrm{a}}$ & $6.89^{d}$ & 6.75 \\
\hline $\left.\mathrm{EC}(\mathrm{dS} \mathrm{m})^{-1}\right)$ & $0.012^{\mathrm{ef}}$ & $0.048^{\mathrm{c}}$ & $0.015^{\mathrm{d}}$ & $0.013^{\mathrm{e}}$ & $0.011^{\mathrm{f}}$ & $0.012^{\mathrm{ef}}$ & $0.012^{\mathrm{ef}}$ & $0.011^{\mathrm{ef}}$ & $0.065^{\mathrm{b}}$ & $0.082^{\mathrm{a}}$ & 0.011 \\
\hline Organic carbon $\left(\mathrm{g} \mathrm{kg}^{-1}\right)$ & $6.93^{\mathrm{i}}$ & $7.95^{\mathrm{h}}$ & $8.11^{\mathrm{e}}$ & $8.45^{\mathrm{a}}$ & $8.17^{\mathrm{c}}$ & $8.07^{\mathrm{f}}$ & $8.14^{\mathrm{d}}$ & $8.26^{\mathrm{b}}$ & $8.11^{\mathrm{e}}$ & $8.05^{\mathrm{g}}$ & 7.40 \\
\hline Total nitrogen $\left(\mathrm{g} \mathrm{kg}^{-1}\right)$ & $0.672^{\mathrm{g}}$ & $0.781^{\mathrm{f}}$ & $0.821^{\mathrm{d}}$ & $0.973^{\mathrm{a}}$ & $0.840^{\mathrm{c}}$ & $0.921^{\mathrm{b}}$ & $0.817^{\mathrm{d}}$ & $0.973^{\mathrm{a}}$ & $0.921^{\mathrm{b}}$ & $0.810^{\mathrm{e}}$ & 0.730 \\
\hline Available $\mathrm{P}\left(\mathrm{Kg} \mathrm{ha}^{-1}\right)$ & $19.51^{\mathrm{j}}$ & $36.26^{\mathrm{a}}$ & $27.30^{\mathrm{h}}$ & $28.90^{\mathrm{g}}$ & $29.42^{\mathrm{f}}$ & $30.37^{\mathrm{d}}$ & $26.52^{\mathrm{i}}$ & $30.61^{\mathrm{c}}$ & $29.89^{\mathrm{e}}$ & $32.78^{\mathrm{b}}$ & 23.35 \\
\hline Available $\mathrm{K}\left(\mathrm{Kg} \mathrm{ha}^{-1}\right)$ & $126^{\mathrm{i}}$ & $184^{\mathrm{a}}$ & $152^{\mathrm{h}}$ & $157^{\mathrm{f}}$ & $171^{\mathrm{c}}$ & $170^{\mathrm{d}}$ & $166^{\mathrm{e}}$ & $158^{\mathrm{f}}$ & $154^{\mathrm{f}}$ & $183^{\mathrm{b}}$ & 150 \\
\hline Microbial biomass carbon $\left(\mu \mathrm{g} \mathrm{g}^{-1}\right)$ & $345^{\mathrm{j}}$ & $425^{\mathrm{i}}$ & $456^{\mathrm{g}}$ & $632^{\mathrm{a}}$ & $556^{\mathrm{c}}$ & $517^{\mathrm{e}}$ & $536^{\mathrm{d}}$ & $558^{\mathrm{b}}$ & $468^{g}$ & $512^{\mathrm{f}}$ & 375 \\
\hline Basal soil respiration $\left(\mu \mathrm{g} \mathrm{g}^{-1}\right)$ & $0.51^{\mathrm{g}}$ & $0.65^{\mathrm{e}}$ & $0.69^{c}$ & $0.89^{\mathrm{a}}$ & $0.65^{\mathrm{e}}$ & $0.66^{\mathrm{d}}$ & $0.75^{\mathrm{b}}$ & $0.89^{\mathrm{a}}$ & $0.63^{f}$ & $0.66^{\mathrm{d}}$ & 0.63 \\
\hline Substrate induced respiration $\left(\mu \mathrm{g} \mathrm{g}^{-1}\right)$ & $2.93^{j}$ & $4.53^{\mathrm{i}}$ & $6.34^{\mathrm{e}}$ & $7.59^{\mathrm{a}}$ & $4.56^{\mathrm{h}}$ & $4.59^{\mathrm{g}}$ & $6.74^{\mathrm{c}}$ & $7.59^{\mathrm{b}}$ & $5.32^{\mathrm{f}}$ & $6.44^{\mathrm{d}}$ & 4.05 \\
\hline FDHA $\left(\mu g^{-1}\right)$ & $28.39^{j}$ & $45.12^{\mathrm{i}}$ & $54.35^{\mathrm{e}}$ & $55.42^{\mathrm{b}}$ & $48.17^{\mathrm{h}}$ & $54.64^{\mathrm{d}}$ & $53.27^{\mathrm{f}}$ & $55.39^{\mathrm{c}}$ & $49.64^{\mathrm{g}}$ & $56.50^{\mathrm{a}}$ & 34.42 \\
\hline Water soluble carbon $\left(\mu \mathrm{g} \mathrm{g}^{-1}\right)$ & $326^{\mathrm{j}, *}$ & $361^{\mathrm{h}}$ & $367^{\mathrm{g}}$ & $477^{\mathrm{a}}$ & $436^{\mathrm{c}}$ & $384^{\mathrm{f}}$ & $419^{\mathrm{d}}$ & $460^{\mathrm{b}}$ & $355^{\mathrm{i}}$ & $390^{\mathrm{e}}$ & 343 \\
\hline Total carbohydrate carbon $\left(\mu \mathrm{g} \mathrm{g}^{-1}\right)$ & $2144^{\mathrm{j}}$ & $2362^{\mathrm{i}}$ & $2511^{\mathrm{h}}$ & $4871^{\mathrm{a}}$ & $3470^{\mathrm{d}}$ & $2753^{\mathrm{f}}$ & $3549^{\mathrm{c}}$ & $4727^{\mathrm{b}}$ & $2531^{\mathrm{g}}$ & $2853^{\mathrm{e}}$ & 2273 \\
\hline Humus carbon $\left(\mu \mathrm{g} \mathrm{g}^{-1}\right)$ & $1227^{\mathrm{j}}$ & $1396^{\mathrm{i}}$ & $1436^{\mathrm{h}}$ & $2147^{\mathrm{a}}$ & $1601^{\mathrm{d}}$ & $1563^{\mathrm{f}}$ & $1747^{\mathrm{c}}$ & $1922^{\mathrm{d}}$ & $1522^{\mathrm{g}}$ & $1577^{\mathrm{e}}$ & 1328 \\
\hline
\end{tabular}

*Values with the same letter are statistically significant at 5\% probability level by DMRT.

applied along with $50 \% \mathrm{RDF}$. The lowest $\mathrm{pH}$ was recorded in $\mathrm{T}_{8}$ treatment (6.66).

The electrical conductivity (EC) of the experimental soils was non-saline and the effect on EC with the application of different organic and inorganic fertilizer treatments was statistically significant. The highest EC was recorded in $\mathrm{T}_{10}$ treatment $\left(0.082 \mathrm{dSm}^{-1}\right)$ consisting of combined application of $\mathrm{VC}, \mathrm{AZ}$ and PSB; lowest EC could be detected in $\mathrm{T}_{8}$ and $\mathrm{T}_{5}$ treatments $\left(0.011 \mathrm{dSm}^{-1}\right)$.

The treatments which received different organic and inorganic fertilizers showed significant difference on the status of soil organic carbon (OC) after harvest of the sunflower. The application of FYM combined with AZ and PSB $\left(\mathrm{T}_{4}\right)$ resulted in significant increase in OC $\left(8.45 \mathrm{~g} \mathrm{~kg}^{-1}\right)$ over the other treatments. Addition of FYM at the rate of $10 \mathrm{t} \mathrm{ha}^{-1}$ might have helped for the stimulation of the soil microorganisms' activity by the formation of humic acid and thus increased the OC status of the soil $^{18}$. Next in the order was $\mathrm{T}_{8}$ treatment $\left(8.26 \mathrm{~g} \mathrm{~kg}^{-1}\right)$ consisting of application of $5 \mathrm{tha}^{-1} \mathrm{VC}$ with $\mathrm{AZ}$ and PSB. This might be due to the additive effect of $\mathrm{VC}$ coupled with strains of biofertilizers in maintaining higher $\mathrm{OC}^{19}$ and recycling of organic materials in the form of crop residues like root and leaf fall ${ }^{20}$.

The total $\mathrm{N}$ status of the experimental soils showed significant increase with the application of organic and inorganic fertilizers. The treatments supplied with organic fertilizers either alone or in combination with inorganic fertilizers had higher total $\mathrm{N}$ than the sole inorganic fertilizer treatment $\left(\mathrm{T}_{2}\right)$. The highest total $\mathrm{N}$ status was observed in $\mathrm{T}_{4}$ treatment $\left(0.973 \mathrm{~g} \mathrm{~kg}^{-1}\right)$ followed by $\mathrm{T}_{8}$ treatment $\left(0.971 \mathrm{~g} \mathrm{~kg}^{-1}\right)$. The increase in total $\mathrm{N}$ with the application of organics coupled with biofertilizers might be attributed to faster proliferation of soil microbes which could convert organically bound $\mathrm{N}$ to inorganic form ${ }^{21}$.

Similar to the total N, available P content of the soil among different treatments was influenced by the combined application of organic and inorganic fertilizers. Values showed that $T_{2}$ treatment was recorded with highest available $\mathrm{P}$ of $36.26 \mathrm{~kg} \mathrm{ha}^{-1}$ and the lowest was recorded in $\mathrm{T}_{1}$ treatment with $19.51 \mathrm{~kg} \mathrm{ha}^{-1}$. Application of $100 \%$ recommended dose of $\mathrm{P}$ as a component in the sole fertilizer treatment resulted in highest available $\mathrm{P}$ status of the soil. The higher availability of $\mathrm{P}$ with addition of organics over control was attributed to the solubilizing effect of native soil $\mathrm{P}$ and due to the microbial activities, the mineralization of organic $P$ occurred which helped to enhance its mobility in the soil. The treatments receiving PSB in conjunction with FYM/VC showed higher available $\mathrm{P}$ than the treatments without PSB. The addition of PSB had helped in increasing the available P by solubilizing the unavailable forms of $\mathrm{P}$ in soil ${ }^{22}$.

The significantly highest available $\mathrm{K}$ in soil could be detected in the $\mathrm{T}_{2}$ treatment $\left(184 \mathrm{~kg} \mathrm{ha}^{-1}\right)$. The application of different bio-organics in conjunction has helped in the increment of available $\mathrm{K}$ status of soil over control. Such beneficial effect of organics on soil K was reported $^{23}$.

The MBC was recorded with higher value in $\mathrm{T}_{4}$ treatment $\left(632 \mu \mathrm{g} \mathrm{g}^{-1}\right)$ and the lowest in $\mathrm{T}_{1}$ treatment $\left(345 \mu \mathrm{g} \mathrm{g}^{-1}\right)$. In general, all the treatments with bioorganics in combination showed higher $\mathrm{MBC}$ than the sole fertilizer treatment $\mathrm{T}_{2}\left(425 \mu \mathrm{g} \mathrm{g}^{-1}\right)$. Chemical fertilizers may not provide the sufficient soil OC which is necessary as a microbial substrate, thereby decrease in MBC was observed when compared with organic fertiliz$\mathrm{ers}^{24}$. Addition of bio-organics increased the availability of carbon substrate in the form of FYM/VC and direct addition of beneficial microbes in the form of biofertilizers, in turn increase the MBC content of the soil. The variation of $\mathrm{MBC}$ between different treatments with various bio-organics resulted from the content and quality of $\mathrm{OC}$ and also due to the effect of various types of fertilizers on the sunflower crop as well as soil environment. 
Similar to MBC, application of different treatments also significantly influenced the BSR. Highest BSR could be seen in $\mathrm{T}_{4}$ treatment $\left(0.89 \mu \mathrm{g} \mathrm{g}^{-1}\right)$ and the lowest in $\mathrm{T}_{1}$ treatment $\left(0.51 \mu \mathrm{g} \mathrm{g}^{-1}\right)$. All the treatments recorded higher BSR than the initial value prior to the experiment. SIR, which is an indicator of the active microbial population clearly indicated that microbial population was more active in $\mathrm{T}_{4}$ and $\mathrm{T}_{8}$ treatments $\left(7.59 \mu \mathrm{g} \mathrm{g}^{-1}\right)$ than the other treatments.

FDHA was recorded highest in the treatments with combined application of FYM/VC and biofertilizers than the treatment receiving only recommended dose of chemical fertilizers $\left(\mathrm{T}_{2}\right)$ and control (without any fertilizer) treatment $\left(T_{1}\right)$. The highest FDHA was detected in $T_{10}$ treatment $\left(56.50 \mu \mathrm{g} \mathrm{g}^{-1}\right)$ while it was lowest in $\mathrm{T}_{1}$ treatment $\left(28.29 \mu \mathrm{g} \mathrm{g}^{-1}\right)$. The assay of FDHA provides the activities of enzymes like lipase, esterase and protease in soil. Data clearly indicated that $\mathrm{T}_{10}$ treatment maintained higher activities of these enzymes than other treatments.

The water soluble carbon, which is one of the most labile fractions of soil OC, is readily available to the soil microorganisms as an energy source. Higher the water soluble carbon, higher will be the microbial function and hence higher soil fertility. The control treatment (326 $\mu \mathrm{g} \mathrm{g}^{-1}$ ) showed the lowest water soluble carbon than other treatments and the initial value. The reduction was the effect of sunflower crop cultivation without any form of nutrient supplements either inorganic or organic. $T_{4}$ treatment $\left(477 \mu \mathrm{g} \mathrm{g}^{-1}\right)$ had the highest water soluble carbon. Treatments with conjoint application of various organic sources and biofertilizers recorded higher water soluble carbon than treatment with only recommended dose of chemical fertilizers. The total carbohydrate carbon status of the treated soils with integration of different inorganic and organic supplements varied similarly between the treatments as in water soluble carbon. The highest total carbohydrate carbon was in $\mathrm{T}_{4}\left(4871 \mu \mathrm{g} \mathrm{g}^{-1}\right)$ followed by statistically and significantly lower value in $\mathrm{T}_{8}$ treatment $\left(4727 \mu \mathrm{g} \mathrm{g}^{-1}\right)$. The humus carbon fraction in

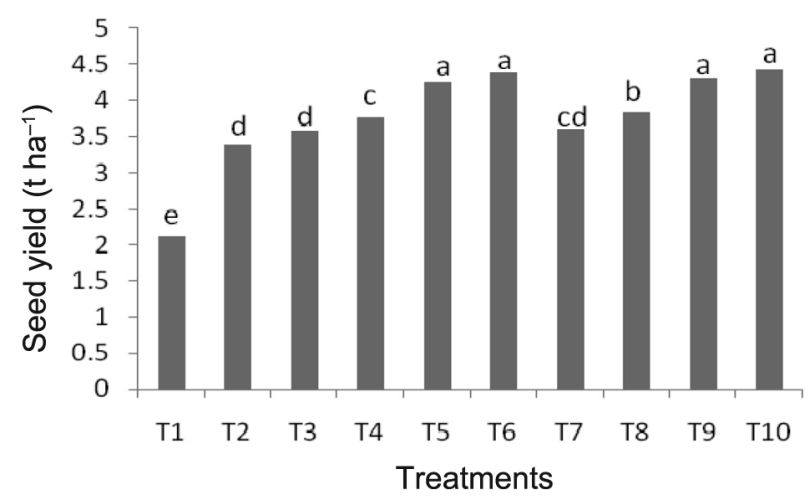

Figure 1. Effect of different treatments on seed yield of sunflower Values with the same letter are statistically significant at $5 \%$ probability level by DMRT. soil is not easily available to the soil microorganisms, but with time it may be hydrolyzed to get utilized by the microorganisms. The highest humus carbon was recorded in $\mathrm{T}_{4}$ treatment $\left(2147 \mu \mathrm{g} \mathrm{g}^{-1}\right)$ and the lowest in $\mathrm{T}_{1}$ $\left(1227 \mu \mathrm{g} \mathrm{g}^{-1}\right)$. The other treatments could be ranked as $\mathrm{T}_{8}>\mathrm{T}_{7}>\mathrm{T}_{5}>\mathrm{T}_{10}>\mathrm{T}_{6}>\mathrm{T}_{9}>\mathrm{T}_{2}$.

The data of seed yield graphically represented in Figure 1 clearly indicated significant statistical difference among the treatments. The highest yield of sunflower seeds was recorded in $T_{10}$ treatment $\left(4.42 \mathrm{~h} \mathrm{ha}^{-1}\right)$ followed by treatments $\mathrm{T}_{9}\left(4.32 \mathrm{tha}^{-1}\right), \mathrm{T}_{5}$ and $\mathrm{T}_{6}$ without having any statistically significant difference between themselves. The other treatments could be ranked as $\mathrm{T}_{6}>\mathrm{T}_{9}>\mathrm{T}_{5}>\mathrm{T}_{8}>\mathrm{T}_{4}>\mathrm{T}_{7}>\mathrm{T}_{3}>\mathrm{T}_{2}$. The treatments comprising of integrated application of fertilizers and organics contributed $68.07 \%$ to $107.51 \%$ increase of seed yield while it was $59.62 \%$ in the sole fertilizer treatment over control. Similar findings were also stated by Kalaiyarasan and Vaiyapuri ${ }^{25}$ and Raju et al. ${ }^{26}$.

Integrated nutrient management holds great promise in meeting the growing nutrient demand of modern agriculture. It can also help in maintaining production sustainability without deterioration of the soil health and crop quality. The present field experiment clearly stated that the application of VC $\left(2.5 \mathrm{tha}^{-1}\right)$ or FYM $\left(5 \mathrm{tha}^{-1}\right)$ with AZ, PSB and 50\% recommended doses of chemical fertilizers in alluvial soil with foliar spray of $2 \%$ urea (treatment $-\mathrm{T}_{10} / \mathrm{T}_{6}$ ) in sunflower, was the best possible combination for higher yield of the seed. The study ths indicated that the integrated application of the organics along with inorganic fertilizers resulted in maintaining higher chemical, microbiological, biochemical parameters of soils and increased seed yields of sunflower.

1. Efthimiadou, A., Bilalis, D., Karkanis, A. and Williams, B. F., Combined organic/inorganic fertilization enhances soil quality and increased yield, photosynthesis and sustainability of sweet maize crop. Aust. J. Crop Sci., 2010, 4(9), 722-729.

2. Kumar, T., Kumar, M., Singh, M. K., Kumar, V., Kumar, S. and Singh, B., Impact of integrated nutrient management (INM) on growth and economic yield of Okra. Ann. Hortic., 2013, 6(1), 107-114.

3. Meena, B. P., Biswas, A. K., Singh, M., Chaudhary, R. S., Singh, A. B., Das, H. and Patra, A. K., Long-term sustaining crop productivity and soil health in maize-chickpea system through integrated nutrient management practices in Vertisols of Central India. Field Crops Res., 2019, 232, 62-76.

4. Bohme, L., Langer, U. and Bohme, F., Microbial biomass, enzyme activities and microbial community structure in two European long-term field experiments. Agric. Ecosyst. Environ., 2005, 109, $141-152$.

5. Pocket book of Agricultural statistics, 2018; https://www. nfsm.gov.in/ReadyReckoner/Oilseeds/Stat_OS2018.pdf

6. https://www.indiastat.com/table/agriculture/2/sunflower/19581/ 1131624/data.aspx

7. Sengupta, K. and Das, P. K., Cultivated Annual Oilseed Crops of India, Naya Udyog, Kolkata, 2003, p. 295.

8. Jackson, M. L., Soil Chemical Analysis, Prentice Hall of India Pvt Ltd, New Delhi, India, 1973, p. 498. 
9. Walkley, A. and Black, I. A., An examination of the Degtjareff method for determining soil organic matter, and a proposed modification of the chromic acid titration method. Soil Sci., 1934, 37(1), 29-38.

10. Sankaram, A., A Laboratory Manual for Agricultural Chemistry, Asia Publishing House, Calcutta, India, 1966.

11. Olsen, S. R., Estimation of available phosphorus in soils by extraction with sodium bicarbonate. US Department of Agriculture - Circular 939, 1954, pp. 1-9.

12. Schollenberger, C. J. and Simon, R. H., Determination of exchange capacity and exchangeable bases in soil-ammonium acetate method. Soil Sci., 1945, 59(1), 13-24.

13. Vance, E. D., Brookes, P. C. and Jenkinson, D. S., An extraction method for measuring soil microbial biomass carbon. Soil Biol. Biochem., 1987, 19, 703-707.

14. Alef, K., Soil respiration. In Methods in Soil Microbiology and Biochemistry (eds Alef, K. and Nannipieri, P.), Academic Press, London, UK, 1995, pp. 214-219.

15. Alef, K., Estimation of the hydrolysis of fluorescein diacetate. In Methods in Soil Microbiology and Biochemistry (eds Alef, K. and Nannipieri, P.), Academic Press, London, UK, 1995, pp. 232-233.

16. Brink Jr, Dubach, R. H. and Lynch, D. L., Measurement of carbohydrates in soil hydrolyzates with anthrone. Soil Sci., 1960, 89, 157-166.

17. Kononova, M. M., Soil Organic Matter: Its Nature, Its Role in Soil Formation and in Soil Fertility, Pergamon Press, Oxford, London, 1966, 2nd edn, p. 554.

18. Prasad, J., Karmakar, S., Kumar, R. and Mishra, B., Influence of integrated nutrient management on yield and soil properties in maize-wheat cropping system in an Alfisol of Jharkhand. J. Indian Soc. Soil Sci., 2010, 58(2), 200-204.

19. Shahina, T., Sammi Reddy, K., Vaishya, U. K., Singh, M. and Biswas, A. K., Changes in organic and inorganic forms of nitrogen in a Typic Haplustert under soybean-wheat system due to conjoint use of inorganic fertilizers and organic manures. J. Indian Soc. Soil Sci., 2010, 58(1), 78-85.

20. Singh, R. N., Singh, S., Prasad, S. S., Singh, V. K. and Kumar, P., Effect of integrated nutrient management on soil fertility, nutrient uptake and yield of rice-pea cropping system on an upland acid soil of Jharkhand. J. Indian Soc. Soil Sci., 2011, 59, 158-163.

21. Vipin Kumar and Singh, A. P., Long-term effect of green manuring and farmyard manure on yield and soil fertility status in rice-wheat cropping system. J. Indian Soc. Soil Sci., 2010, 58, 409-412.

22. Bhandari, A. L., Walia, S. S. and Singh, T., Production sustainability of maize-wheat system in a Typic Ustipsamment soil as influenced by integrated nutrient sources. In Proceedings of International Conference on Managing Natural Resources for Sustainable Agriculture Production in the 21th Century, New Delhi, 2000, vol. 3, pp. 889-890.

23. Sawarkar, S. D., Khamparia, N. K., Thakur, R., Dewda, M. S. and Singh, M., Effect of long-term application of inorganic fertilizers and organic manure on yield, potassium uptake and profile distribution of potassium fraction in vertisol under soybeanwheat cropping system. J. Indian Soc. Soil Sci., 2013, 61(2), 94-98.

24. Fereidooni, M., Raiesi, F. and Fallah, S., Ecological restoration of soil respiration, microbial biomass and enzyme activities through broiler litter application in a calcareous soil cropped with silage maize. Ecol. Eng., 2013, 58, 266-277.

25. Kalaiyarasan, C. and Vaiyapuri, V., Effect of integrated nutrient management practices on seed yield and quality characters of sunflower (Helianthus annuus L.). Int. J. Agric. Sci., 2008, 4(1), 231-233.

26. Raju, B., Rao, P. C., Reddy, A. and Rajesh, K., Effect of INM on nutrient uptake and seed yield in safflower. Ann. Biol. Res., 2013, 4(7), 222-226.
ACKNOWLEDGEMENTS. We thank Agricultural Experimental Farm, University of Calcutta, Baruipur for providing support in carrying this study during field as well as laboratory analysis. We acknowledge Department of Agricultural Chemistry and Soil Science, University of Calcutta for instrumental facilities as well as financial assistance.

Received 21 March 2019; revised accepted 12 September 2019

doi: $10.18520 / \mathrm{cs} / \mathrm{v} 117 / \mathrm{i} 8 / 1364-1368$

\section{Genetic lineage of Zeugodacus caudatus (Diptera: Tephritidae) detected with $m t C O I$ gene analysis from India}

\author{
Chandra S. Prabhakar ${ }^{1,2,3, *}$, Anil ${ }^{4,7}$, \\ Jaipal S. Choudhary ${ }^{2}$, Ravi S. Singh ${ }^{5}$, S. N. Ray ${ }^{4}$, \\ Kalmesh Managanvi ${ }^{6}$, Mona Kumari ${ }^{5}$, \\ Ashok B. Hadapad ${ }^{3}$ and Ramesh S. Hire ${ }^{3}$
}

${ }^{1}$ Department of Entomology, Veer Kunwar Singh College of Agriculture, Dumraon (Bihar Agricultural University, Sabour), Buxar 802 136, India

${ }^{2}$ ICAR Research Complex for Eastern Region, Research Centre, Plandu, Ranchi 834 010, India

${ }^{3}$ Nuclear Agriculture and Biotechnology Division,

Bhabha Atomic Research Centre, Trombay, Mumbai 400 094, India

${ }^{4}$ Department of Entomology, Bihar Agricultural College,

Bihar Agricultural University, Sabour, Bhagalpur 813210 , India

${ }^{5}$ Department of Plant Breeding and Genetics, Bihar Agricultural

College, Bihar Agricultural University, Sabour,

Bhagalpur 813210 , India

${ }^{6}$ Department of Entomology, Dr Kalam Agriculture College, Kishanganj 855107 (Bihar Agricultural University, Sabour), India ${ }^{7}$ Department of Genetics and Plant Breeding (Cotton Section), Chaudhary Charan Singh Haryana Agricultural University, Hisar 125 004, India

\begin{abstract}
Zeugodacus caudatus (Fabricius) is a pest of cucurbit plants. The present study was conducted to draw the relationship among Indian $Z$. caudatus populations with the other defined genetic lineage of the species. A total of 18 individuals' $m$ tCOI gene sequences from 3 populations of India were analysed along with 34 individuals' mtCOI gene sequences from Malaysia, Indonesia, Thailand and China and generated 14 haplotypes. Phylogenetic study revealed the presence of distinct genetic lineage in $Z$. caudatus populations collected from India. The genetic distance between three distinct lineages of $Z$. caudatus was $0.057,0.055$ and 0.018 between Indonesia and Malaysia, India and
\end{abstract}

\footnotetext{
*For correspondence. (e-mail: csprabhakar.ento@gmail.com)
} 